\title{
MAKALAH AKTIVITAS LOMPAT JAUH
}

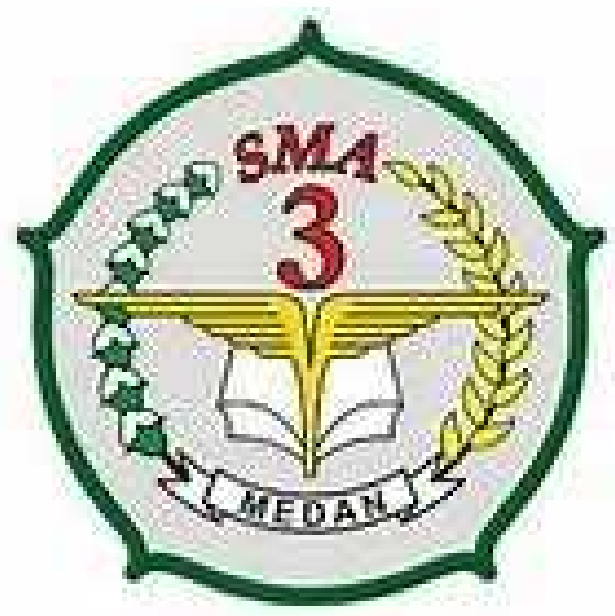

\author{
OLEH \\ Raihan Abrar \\ X MIA 3 \\ SMA NEGERI 3 MEDAN \\ T.A. $2019 / 2020$
}





\section{Kata pengantar}

Puji syukur penulis ucapakan kepada Allah SWT, yang telah memberikan rahmat dan karunia-Nya sehingga makalah yang berjudul "aktivitas Lompat Jauh" ini dapat diselesaikan dengan baik. Tidak lupa shalawat dan salam semoga terlimpahkan kepada Rasulullah Muhammad SAW, keluarganya, sahabatnya, dan kepada kita selaku umatnya.

Makalah ini penulis buat untuk melengkapi tugas pelajaran PJOK. Saya ucapkan terima kasih kepada semua pihak yang telah membantu dalam penyusunan makalah ini. Dan saya juga menyadari akan pentingnya sumber bacaan dan referensi internet yang telah membantu dalam memberikan informasi yang akan menjadi bahan makalah.

Saya juga mengucapkan terima kasih kepada bapak guru Suyono S.Pd, M.Or sebagai guru bidang studi yang telah banyak memberi petunjuk dan semua pihak yang telah memberikan arahan serta bimbingannya selama ini sehingga penyususan makalah dapat dibuat dengan sebaikbaiknya. Saya menyadari masih banyak kekurangan dalam penulisan makalah ini sehingga saya mengharapkan kritik dan saran yang bersifat membangun demi penyempurnaan makalah ini.

Saya mohon maaf jika di dalam makalah ini terdapat banyak kesalahan dan kekurangan, karena kesempurnaan hanya milik Yang Maha Kuasa yaitu Allah SWT, dan kekurangan pasti milik kita sebagai manusia. Semoga makalah ini dapat bermanfaat bagi kita semua.

Medan, 25 April 2020 


\section{Daftar Isi}

Judul

Kata Pengantar

Daftar Isi

Abstrak.

$\ldots .1$

Contents

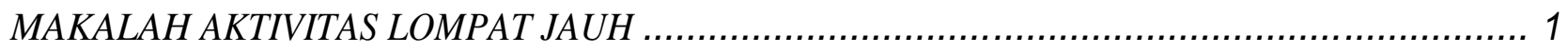

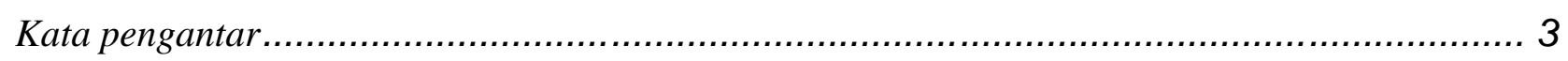

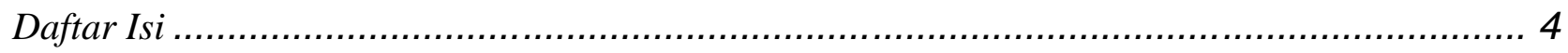

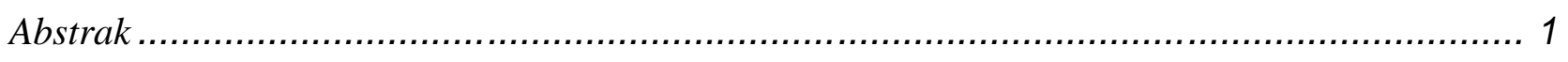

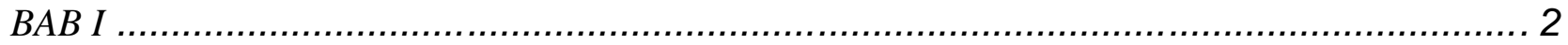

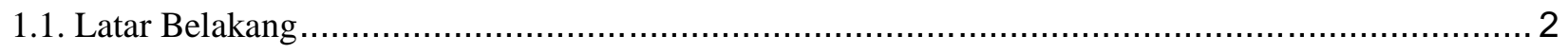

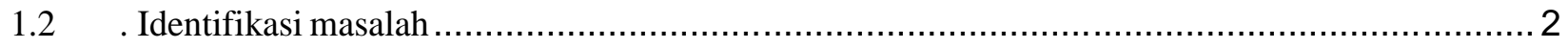

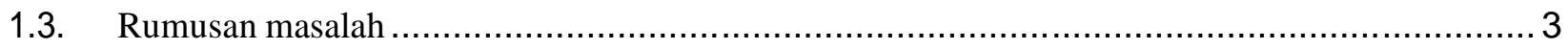

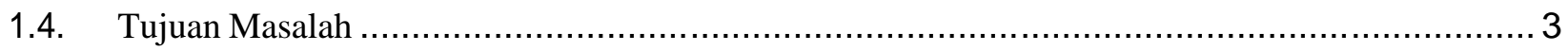

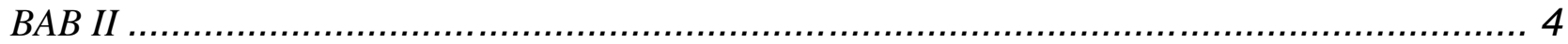

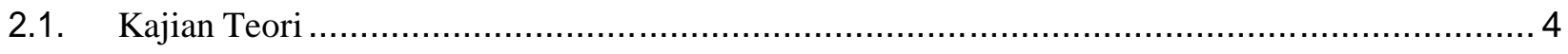

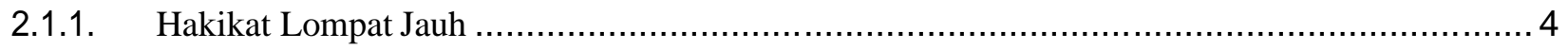

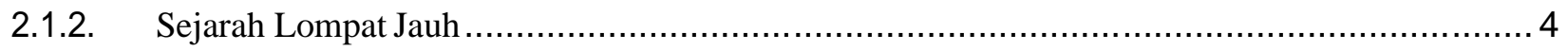

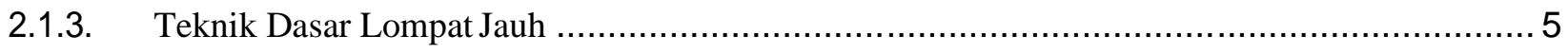

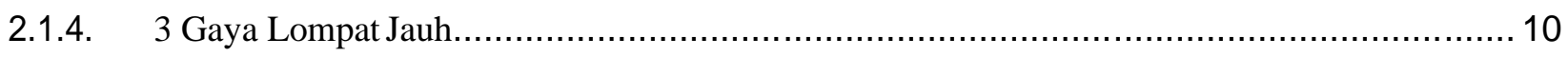

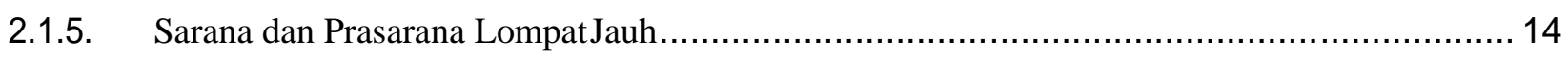

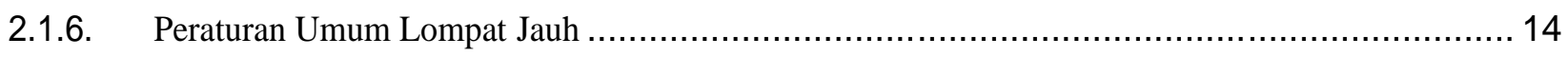

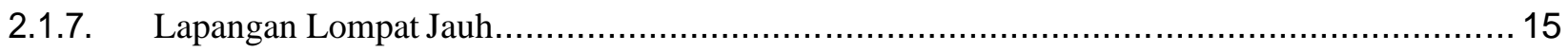

2.1.8. Faktor Yang Mempengaruhi LompatJauh......................................................... 16 


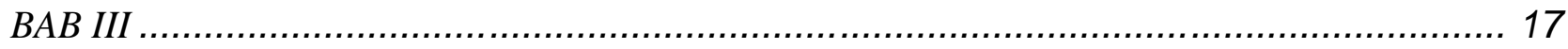

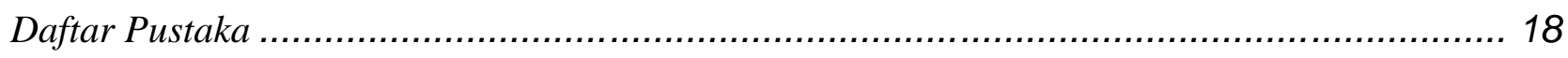





\begin{abstract}
Abstrak
Tujuan : Olahraga merupakan hal yang sangat penting bagi tubuh kita. Melalui olahraga dapat dibentuk manusia yang sehat jasmani, rohani serta mempunyai kepribadian, disiplin, sportifitas yang tinggi sehingga pada akhirnya akan terbentuk manusia yang berkualitas. Banyak cabang olahraga yang dapat dilakukan untuk meningkatkan kesehatan fisik, salah satunya olahraga atletik. Salah satu cabang olahraga atletik lompat jauh. Dengan mempelajari permainan lompat jauh, kita dapat melakukan gerakan melompat ke depan atas dengan usaha agar badan melayang di udara yang dilakukan dengan cepat dan dengan cara melakukan tolakan satu kaki untuk memperoleh jarak sejauh-jauhnya.

Dalam kehidupan modern manusia tidak dapat dipisahkan dari olahraga, baik sebagai arena adu prestasi maupun sebagai kebutuhan untuk menjaga kondisi tubuh agar tetap sehat. Olahraga mempunyai peranan yang penting dalam kehidupan manusia. Melalui olahraga dapat dibentuk manusia yang sehat jasmani, rohani serta mempunyai kepribadian, disiplin, sportifitas yang tinggi sehingga pada akhirnya akan terbentuk manusia yang berkualitas.

Kata Kunci : Sehat, lompat jauh, sportifitas.
\end{abstract}




\section{BAB I}

\section{Pendahuluan}

\subsection{Latar Belakang}

Dalam kehidupan modern manusia tidak dapat dipisahkan dari olahraga, baik sebagai arena adu prestasi maupun sebagai kebutuhan untuk menjaga kondisi tubuh agar tetap sehat. Olahraga mempunyai peranan yang penting dalam kehidupan manusia. Melalui olahraga dapat dibentuk manusia yang sehat jasmani, rohani serta mempunyai kepribadian, disiplin, sportifitas yang tinggi sehingga pada akhirnya akan terbentuk manusia yang berkualitas.

Dalam lompat jauh terdapat beberapa macam gaya atau sikap badan pada saat melayang di udara. Soegito dkk (1994 : 143) menyebutkan ada tiga cara sikap melayang yaitu: 1) gaya jongkok (waktu melayang bersikap jongkok), 2) gaya lenting (waktu di udara badan dilentingkan), dan 3) gaya jalan di udara (waktu melayang kaki bergerak seolah-olah berjalan di udara). Gaya lompat jauh yang paling sederhana untuk diajarkan pada pemula seperti siswa di SD adalah lompat jauh gaya jongkok. Tehnik lompat jauh gaya jongkok termasuk yang paling sederhana di banding dengan gaya yang lain.

\section{2 . Identifikasi masalah}

Dari latar belakang yang sudah disebutkan di atas, serta belum adanya data penelitian tentang hubungan aktivitas dengan lompat jauh. Maka diperlukan penelitian lebih lanjut untuk aktivitas tersebut. 


\subsection{Rumusan masalah}

Dalam makalah yang berjudul aktivitas lompat jauh mengangkat masalah- masalah sebagai berikut:

1. Apa pengertian dari lompatjauh?

2. Bagaimana sejarah dari lompatjauh?

3. Apa saja teknik dasar lompatjauh?

4. Apa saja 3 gaya lompatjauh?

5. Apa saja sarana dan prasarana lompat jauh?

6. Apa saja peraturan umum dalam lompatjauh?

7. Bagaimana bentuk lapangan lompatjauh?

8. Apa saja faktor yang mempengaruhi lompatjauh?

\subsection{Tujuan Masalah}

Pembuatan makalah ini bertujuan untuk

1. Untuk mengetahui pengertian dari lompatjauh

2. Untuk mengetahui sejarah dari lompatjauh

3. Untuk mengetahui teknik dasar lompatjauh

4. Untuk mengetahui 3 gaya lompat jauh

5. Untuk mengetahui sarana dan prasarana lompatjauh

6. Untuk megetahui peraturan umum lompatjauh 
7. Untuk mengetahui bentuk lapangan lompatjauh

8. Untuk mengetahui faktor yang mempengaruhi lompatjauh

\section{BAB II}

\section{Pembahasan}

\subsection{Kajian Teori}

\subsubsection{Hakikat Lompat Jauh}

Lompat jauh merupakan salah satu cabang olahraga atletik yang populer dan sering dilombakan dalam kompetisi kelas dunia, termasuk Olimpiade. Lompat jauh adalah suatu gerakan melompat ke depan atas dengan usaha agar badan melayang di udara yang dilakukan dengan cepat dan dengan cara melakukan tolakan satu kaki untuk memperoleh jarak sejauhjauhnya.

\subsubsection{Sejarah Lompat Jauh}

Sejarah lompat jauh bermula ketika 13 abad lalu, olahraga lompat jauh muncul tahun 708 Masehi saat ada Olimpiade Kuno di Yunani. Sejarah mencatat bahwa olahraga ini juga pernah dilakukan oleh peserta Spartadengan panjang lompatan 7,05 meter. Awalnya event dalam Olimpiade Kuno diadakan untuk tujuan latihan militer perang. Lompat jauh dipercaya bisa melatih ketangkasan prajurit perang dalam melompati rintangan seperti jurang atau parit. Terdapat perbedaan teknik antara lompat jauh dahulu dengan teknik lompat jauh pada saat ini. Tak hanya dari segi teknik, peserta 
juga hanya diperkenankan untuk berlari dalam jarak yang pendek dengan membawa beban di kedua tangannya yang biasanya dikenal dengan sebutan halteres. Berat beban tersebut kurang lebih sekitar 1 sampai 4,5 kg. Olimpiade modern pertama kali diperkenalkan dan dilaksanakan pada tahun 1896. Pada tahun tersebut olahraga lompat jauh juga untuk pertamakalinya dilombakan secararesmi.

\subsubsection{Teknik Dasar Lompat Jauh}

Teknik dasar lompat jauh terbagi 4 yaitu awalan, tolakan, melayang di udara, dan pendaratan. Dan untuk mendapatkan lompatan yang jauh maka kamu perlu menyerasikan ke 4 hal tersebut.

1. Awalan

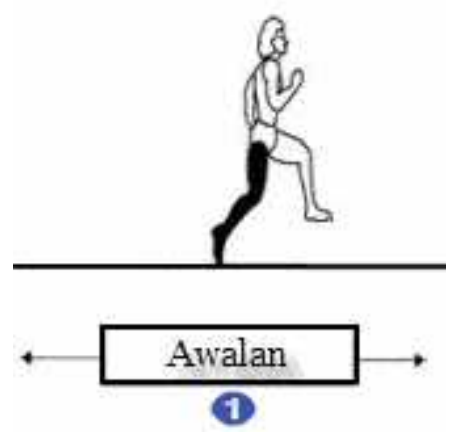

Teknik awalan lari yaitu dari lari perlahan ke lari cepat, dan harus terkendali dan memungkinkan untuk melakukan tolakan. Jangan sampai melebihi garis tolakan yang sudah ditetapkan. 
Disaat mendekati papan tolakan sekitar 3-4 langkah, kamu harus siap mengganti kecepatan gerak lari ke kecepatan tolakan dengan langkah terakhir yang pendek. Selain itu, awalan dalam atletik lompat jauh dapat diartikan sebagai suatu upaya untuk memperoleh kecepatan horizontal maksimal yang kemudian diubah menjadi kecepatan vertikal ketika melakukan tolakan.

Jarak dari suatu awalan tergantung dari tingkat kematangan dari atlet tersebut dan kemampuan dari atlet tersebut untuk berakselerasi dengan kecepatannya sendiri.Teknik awalan harus dilakukan dengan berlari secepat mungkin dari jarak 40-45 meter pada sebuah lintasan lari.

Ada beberapa hal yang harus diperhatikan saat melakukan awalan dalam cabang atletik lompat jauh, seperti :

- Jarak awalan dalam cabang atletik lompat jauh bergantung pada kemampuan atlet itu sendiri. Bagi para pelompat yang dalam jarak pendek sudah dapat mencapai kecepatan maksimal, jarak awalan cukup pendek atau dekat saja (kurang lebih 30- 35 meter atau kurang dari itu).Sementara itu, bagi para atlet lompat jauh yang mencapai kecepatan maksimal dalam jarak relatif jauh, jarak awalan harus lebih jauh (kurang lebih 30-45 meter atau lebih dari itu).

- Posisi ketika berdiri di titik awalan pada lompat jauh yaitu kaki posisi sejajar atau bisa juga salah satu kaki berada di depan, tergantung dari kebiasaan atlet itu sendiri. Cara pengambilan awalan dalam lompat jauh dimulai dari perlahan-lahan dan kemudian cepat (sprint).Kecepatan ini harus dipertahankan hingga sesaat sebelum melakukan tumpuan/tolakan.

- Setelah mencapai kecepatan maksimal, sekitar 3-4 langkah terakhir bertumpu (take -off) gerakan lari dilepas secara spontan tanpa mengurangi kecepatan yang telah dicapai sebelumnya. Pada langkah terakhir ini, konsentrasi dan tenaga fokus untuk melakukan tumpuan di papan atau balok tumpu. 
2. tolakan

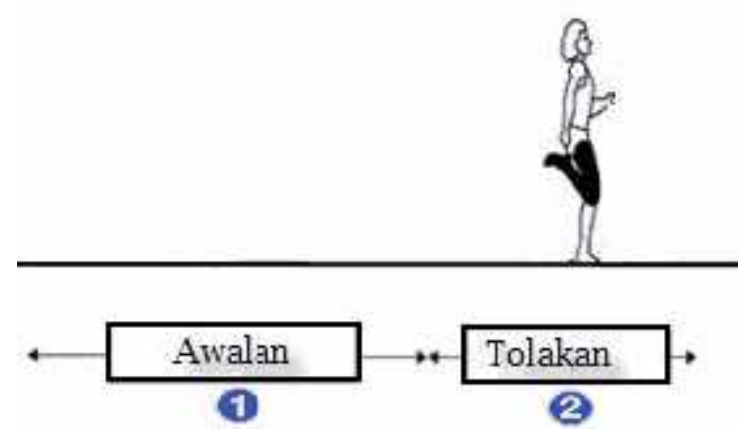

Langkah berikutnya setelah awalan yaitu tolakan, tolakan bertujuan agar tubuh terangkat ke atas dan melayang di udara. Tolakan berpengaruh besar terhadap jarak lompatan yang diperoleh.Perlu diperhatikan, saat melakukan tolakan usahakan kaki sedikit ditekuk, menapakkan kaki, dan meluruskan tungkai untuk lepas landas. Gerakan tolakan yang baik membutuhkan kekuatan, kecepatan, dan koordinasi gerakan yang memadai.

Cara melakukan tolakan/tumpuan:

1. Ayunkan paha dan kaki ke posisi horizontal dan dipertahankan.

2. Luruskan sendi mata kaki, lutut, dan pinggang pada saat melakukan tolakan.

3. Bertolak ke depan dan ke atas.

4. Sudut tolakan 45 derajat.

3. Melayang di Udara 

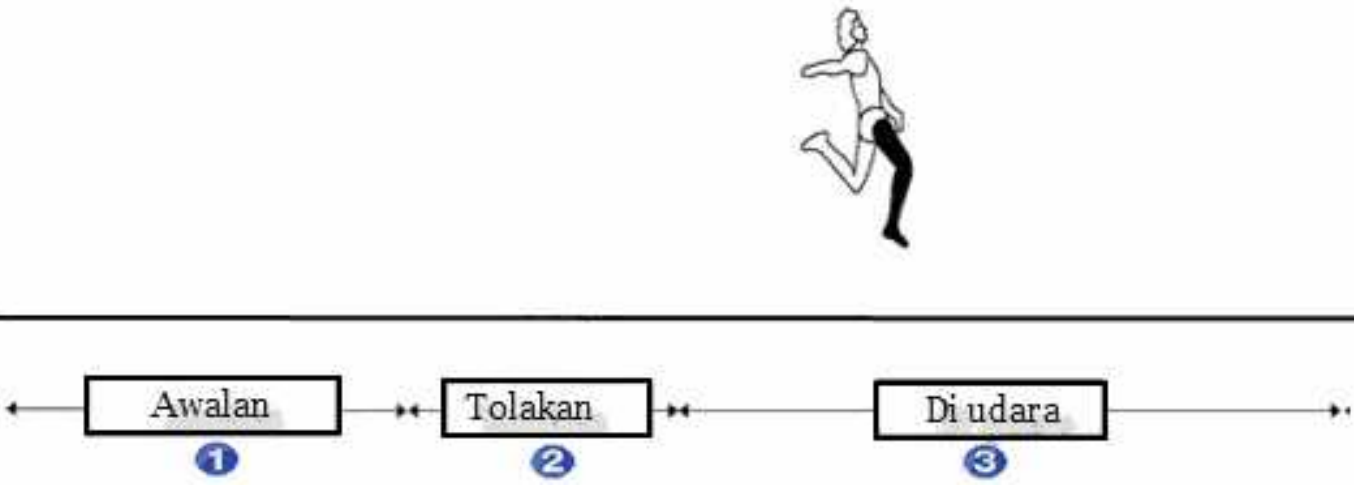

Di saat tubuh melayang di udara, usahakan agar tubuh tetap seimbang. Salah satu tips saat kondisi ini yaitu gerakan kaki seperti berjalan. Sehingga berjalan selama melayang di udara akan mempermudah kamu untuk melakukan pendaratan yang baik.

Ada 2 cara dalam melakukan teknik melayang yaitu :

- Dengan sikap jongkok Dalam sikap ini, saat menumpu, kaki ayun mengangkat lutut setinggi-tingginya, lalu disusul dengan kaki tumpu. Kemudian sebelum melakukan pendaratan, kedua kaki dibawa kedepan.

- Dengan sikap menggantung Dalam sikap ini, kaki ayun dibiarkan tergantung lurus pada waktu menumpu. Tubuh diusahakan tegak, disusul oleh kaki tumpu dengan lutut ditekuk sambil pinggul didorong ke depan. Lalu, kedua lengan direntangkanke atas.

Hal yang perlu diperhatikan saat tubuh melayang di udara:

- Menjaga keseimbangan badan.

- Mengusahakan tahanan udara sekecil mungkin.

- Mengusahakan melayang di udara selama mungkin.

- Mempersiapkan kaki untuk pendaratan. 


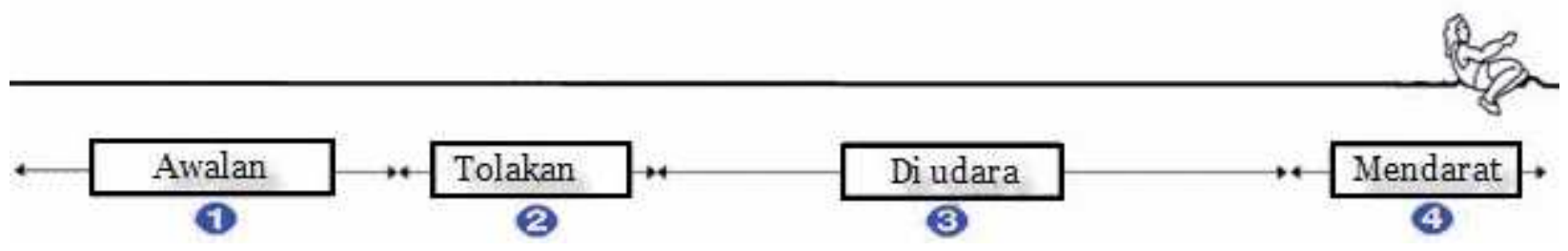

Hal terakhir dalam teknik dasar lompat jauh yaitu pendaratan. Pendaratan dilakukan dengan cara menundukkan kepala, mengayunkan lengan, dan membawa pinggang ke depan.

Hal tersebut bertujuan agar anggota badan yang lain tidak mengenai pasir lebih belakang daripada kaki.

Dalam teknik ini, atlet harus berupaya mendarat dengan sebaik mungkin.Jangan sampai badan atau lengan jatuh ke belakang.Pendaratan pada bak lompat dimulai dengan posisi kedua tumit kaki dan kedua kaki agak rapat.Gerakan-gerakan waktu pendaratan harus dilakukan dengan keduakaki.

Yang perlu diperhatikan saat mendarat dalam lompat jauh adalah kedua kaki mendarat secara bersamaan, diikuti dengan dorongan pinggul ke depan. Sehingga badan tidak cenderung jatuh ke belakang yang dapat berakibat fatal bagi atlet itu sendiri.

Hal yang dapat meningkatkan kemampuan teknik lompat jauh dan menghasilkan lompatan yang jauh. Perhatikan beberapa faktor berikut.

- Penentuan jarak awalan yang tepat.

- Penentuan irama lariawalan.

- Kemampuan tolakan dan lepas landas.

- Kemampuan gerak melayang di udara. 
- Kemampuan gerak saat pendaratan.

\subsubsection{Gaya Lompat Jauh}

\section{Berikut adalah jenis-jenis gaya dalam lompat jauh}

\section{Gaya Jongkok (Ortodok)}

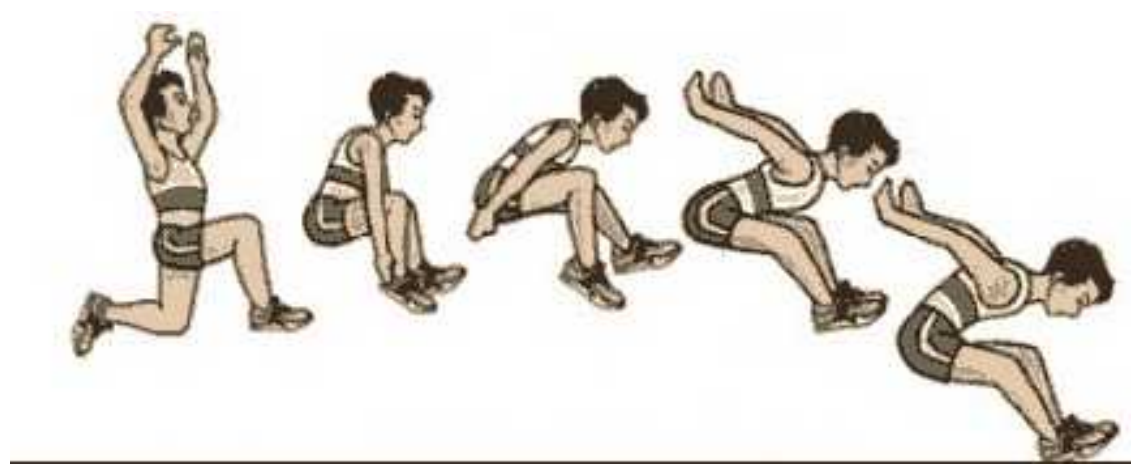

Gaya yang sering dilakukan ketika badan melayang di udara ini berfungsi agar kamu bisa memperoleh kecepatan maksimum ketika i.ngin melompat.

Disaat tolakan, kita biasa menggunakan kaki yang terkuat dan tepat. Nah disaat kita sudah mulai melayang maka mulai tekuk lutut ke atas. Disaat akan mendarat, awali dengan tumit kaki yang sedikit ditekuk dengan posisi badan condong ke depan dan tangan dikibaskan ke belakang tubuh sambil mengatur pendaratan yang benar.

Gaya jongkok merupakan jenis gaya lompat jauh yang paling tua dan paling mudah untuk dilakukan. Dikatakan gaya jongkok karena pada saat melayang di udara, atlet hanya melakukan gerakan menekuk kedua kakinya, sehingga terlihat seperti sedang jongkok.

- Awalan

Berfungsi untuk mendapatkan kecepatan pada waktu akan melompat. Dilakukan dengan lari secepat-cepatnya dari jarak 40-45 m pada sebuah lintasan. Tidak 
diperkenankan untuk merubah kecepatan dan langkah saat akan menolak pada papan tumpuan.

- Tolakan

Merupakan upaya pelompat melakukan tolakan pada papan tumpuan menggunakan kaki yang terkuat dengan mengubah kecepatan horizontal ke kecepatan vertikal. Saat kaki melakukan tolakan, posisi badan lebih ditegakkan, dan kaki belakang serta kedua lengan diayunkan ke depan atas. Urutan tolakan kaki pada papan tumpuan, dimulai dari tumit, telapak kaki diteruskan pada ujung telapak kaki.

- Di udara. Kedua lutut tertekuk Kedua lengan di samping kepala Saat akan mendarat kaki dan lengan diluruskan ke depan bersamaan berat badan di bawa ke depan

- Mendarat

Mendarat pada bak lompat diawali dengan kedua tumit kaki dan kedua kaki agak rapat.

Lutut tertekuk dan mengeper dalam posisi jongkok bersamaan berat badan di bawa ke depan. Ke dua lengan di depan menyentuh tempat pendaratan serta pandangan ke depan.

2. Gaya Menggantung (Schnepper) 


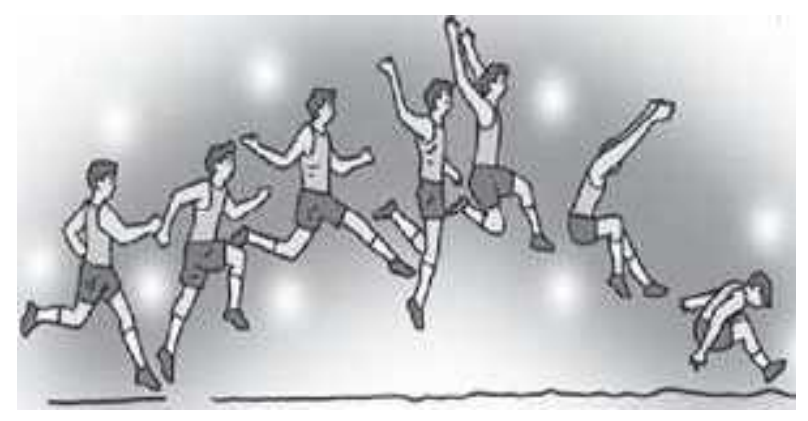

Gaya lompat jauh ini tidak mengubah kecepatan ketika kaki akan bertumpu pada papan tolakan dan cara melakukannya dengan cara badan tegap. Gerakan kaki diayunkan ke belakang dan ke depan bersama dengan kedua lengan. Saat akan melakukan pendaratan, kedua kaki diluruskan kedepan dan kedua tumit mendarat lebih dahulu.

Ada beberapa teknik yang harus diperhatikan disaat melakukan lompat jauh dengan gaya ini, seperti :

- Lakukan awalan dengan kecepatan maksimal dan lakukan tolakan yang sangat kuat pada papan tolakan.

- Pada saat tolakan, kaki tumpu menolak pada papan tumpuan, posisi badan lebih ditegakkan. Urutan tumpuan kaki menolak pada papan tumpuan, mulai dari tumit, telapak kaki diteruskan pada ujung telapak kaki. Gerak mengayun kaki belakang ke depan atas bersamaan dengan kedua lengan

- Pada saat badan di udara, usahakan badan melayang selama mungkin di udara serta dalam keadaan seimbang. Posisikan kedua lengan di atas kepala, seperti memegang tali saat berayun.

- Pada saat mendarat, Dari sikap di udara, kedua lengan luruskan ke depan.

Kedua lutut dan badan dibawa ke depan Saat kedua kaki akan menyentuh tempat pendaratan, luruskan ke depan dan mendarat dengan kedua tumit terlebih dahulu. Saat kedua kaki mendarat kedua lutut mengepet dan berat badan dibawa kedepan. usahakan mendarat dengan sebaik-baiknya, jangan sampai badan atau tangan jatuh ke belakang karena dapat merugikan atlet. 
3. Gaya Berjalan di Udara (Walking in the air)

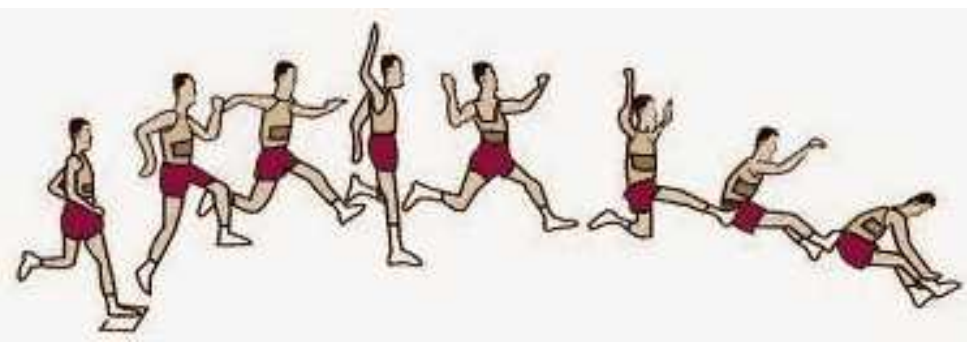

Gaya ini cukup populer karena biasa digunakan oleh para atlet, sebutan kerennya yaitu walking in the air. Cara melakukan gaya ini yaitu sebelum melakukan tolakan, pinggang sedikit diturunkan, paha dan kaki diayunkan secara bebas, luruskan lutut, sendi mata kaki, dan pinggang ketika melakukan tolakan. Kemudian ketika melayang di udara, berjalanlah seperti saat berjalan di tanah. Ketika akan mendarat, lengan dan tubuh ditarik ke depan dan bawah serta kaki diulurkan sesaat. Teknik ini hampir mirip dengan teknik menggantung di udara.

Ada beberapa teknik yang harus diperhatikan disaat melakukan lompat jauh dengan gaya ini, seperti :

1. Lakukan awalan dengan cara lari cepat pada lintasan dengan jarak 40-45 meter. Kemudian lakukan tolakan pada papan tolakan dengan menggunakan kaki yang terkuat untuk mengubah kecepatan horizontal yang dihasilkan pada saat awalan menjadi kecepatan vertikal.

2. pada saat tolakan, ayunkan paha kaki bebas cepat ke posisi horizontal dan pertahankan. Luruskan sendi mata kaki, lutut dan pinggang pada waktu bertolak. Bertolak ke depan atas

3. Pada saat badan melayang di udara, ayunkan kaki ayun atau kaki belakang sekuat- kuatnya ke atas. Selanjutnya lakukan gerakan melangkah di udara dengan melangkahkan kaki yang sebelumnya digunakan untuk menolak atau menumpu hingga membuat gerakan berjalan di udara.

4. Lakukan pendaratan yang aman dan tidak menyebabkan cidera. Caranya dengan meluruskan kedua kaki dan tangan bersama-sama ke depan, badan dicondongkan 
ke depan, dan pada saat tumit menyentuh pasir secara cepat kedua lutut ditekuk.

\title{
2.1.5. Sarana dan Prasarana Lompat Jauh
}

\author{
1. Lintasan Lari Awalan
}

Yang pertama adalah Lintasan. Lintasan standar yang digunakan untuk melakukan ancangancang memiliki ukuran minimum sekitar 40 meter (131 kaki) dengan lebar 1,22 m sampai 1,25 $\mathrm{m}$, lebar $20 \mathrm{~cm}$ dan tebal $10 \mathrm{~cm}$. Dan juga disamping kanan dan kiri lintasan diberi garis putih selebar $5 \mathrm{~cm}$.

\section{Papan Tolak}

Selanjutnya ada papan tolak. Memiliki bentuk segi empat dan biasanya terbuat dari kayu lalu di cat warna putih yang ditanam tak kurang dari 1 meter yang berjarak dari tepi dekat tempat pendaratan. Papan tolak memiliki jara minimal 10 meter dengan sisi terjauh dari tempat pendaratan.

\section{Tempat Pendaratan}

Terakhir adalah tempat pendaratan. Yang mana memiliki lebar minimal 2,175 meter. Didalam tempat pendaratan (bak) ini diisi dengan pasir yang lembut halus dan sedikit basah. dan juga permukaannya harus rata dengan permukaan garis loncat. Jarak garis tolakan dengan ampai akhir tempat lompatan minimal 10 meter.

\subsubsection{Peraturan Umum Lompat Jauh}

adapun peraturan umum pada lompat jauh yaitu:

1. Bila peserta lompat jauh lebih dari 8 orang setiap peserta diperbolehkan 
melompat sebanyak 3 kali. Lompatan diambil yang terjauh. Jika peserta hanya 8 orang atau kurang, maka setiap peserta diperbolehkan melompat sebanyak 6 kali. Melompat dilakukan secara bergiliran.

2. Hasil lompatan diukur dari bekas anggota tubuh terdekat atau paling belakang yang menyentuh bak pasir.

3. Setiap peserta diberi waktu satu giliran selama 1 1/5 menit. Lompatan yang sama ditentukan dengan melihat hasil lompatan yang terbaik. Bila masih sama maka akan dilihat hasil dari lompatan yang ke-3. Demikian seterusnya.

\subsubsection{Lapangan Lompat Jauh}

Panjang lintasan lari hingga papan lompatan atau papan tolak pada umumnya berukuran 40-45 meter dengan lebar lintasan mencapai 1,22 meter. Sementara itu, papan lompatan memiliki panjang 1,22 meter dan lebar $20 \mathrm{~cm}$ dengan ketebalan $10 \mathrm{~cm}$.

Di antara papan lompatan dengan bak lompat terdapat jarak sepanjang 1 meter. Sedangkan bak lompat memiliki panjang 9 meter dengan lebar 2,95 meter. Untuk lebar tempat pendaratan, jaraknya paling sedikit 2,75 meter antara garis tolakan sampai akhir tempat tolakan. Tempat pendaratan diisikan dengan pasir dimana permukaan pasir harus sama tinggi atau datar dengan sisi atas papan tolakan. 


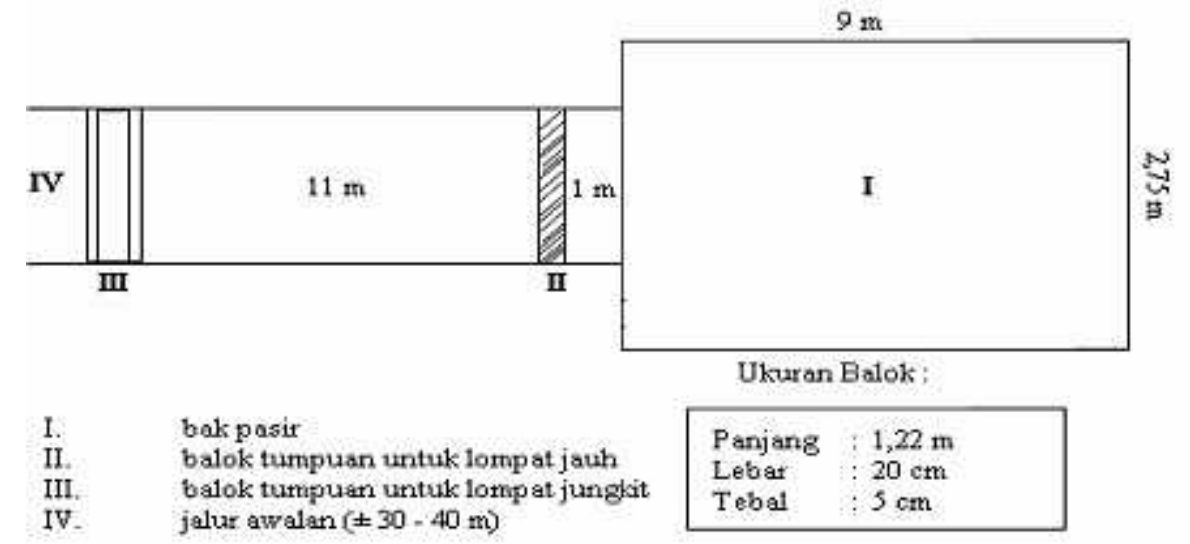

Berikut ini adalah rincian ukuran lapangan lompat jauh dan gambarnya

- Panjang bak lompat $9 \mathrm{~m}$

- Lebar bak lompat $=2,75 \mathrm{~m}$

- Lebar lintasan awalan $=1,22 \mathrm{~m}$

- Lebar papan tumpu $=20 \mathrm{~m}$

- Panjang papan tumpu $=1,22 \mathrm{~m}$

- Bak lompat diisi dengan pasir

\subsubsection{Faktor Yang Mempengaruhi LompatJauh}

1. Faktor yang mempengaruhi prestasi lompat jauh menurut Suharto dalam bukunya dalam bukunya "Kesegaran Jasmani dan Peranannya disebutkan :

2. Kecepatan (speed) adalah kemampuan untuk memindahkan sebagian tubuh atau seluruhnya dari awalan sampai dengan pendaratan. Atau bertumpu pada papan / balok sewaktu melakukan lompatan, kecepatan banyak ditentukan kekuatan dan fleksibelitas

3. Kekuatan (Strenght) adalah jumlah tenaga yang dapat dihasilkan oleh kelompok otot pada kontraksi maksimal pada saat melakukan pekerjaan atau latihan dalam 
melakukan lompatan

4. Daya ledak adalah kemampuan otot dalam melakukan tolakan tubuh melayang di udara saat lepas dari balok tumpu

5. Keseimbangan adalah kemampuan untuk mempertahankan suatu sikap tubuh tertentu secara benar dari awal melakukan lompatan sampai selesai melakukan lompatan

6. Keterampilan adalah kemampuan untuk melakukan suatu gerakan motorik secara benar

7. Koordinasi adalah hal yang harus dimiliki oleh seorang atlet untuk dapat mengkoordinasikan gerakan maju dengan kebutuhan naik

\section{BAB III}

\section{Penutup}

\subsection{Kesimpulan}

Keseluruhan rangkaian gerak teknik lompat jauh terbagi dalam awalan, tolakan, melayang di udara, dan pendaratan. Teknik-teknik dasar ini harus dikuasai dengan baik untuk mendapatkan koordinasi gerak yang baik sehingga menghasilkan jarak lompatan yang jauh. Gaya yang terdapat dalam lompat jauh yaitu gaya jongkok, gaya menggantung, dan gaya berjalan di udara.

\subsection{Saran}

Makalah yang sederhana ini hendaknya dijadikan motivasi belajar bagi pembaca 
untuk mengetahui bagaimana pelaksanaan lompat jauh yang baik dan benar serta dapat memperluas wawasan tentang pendidikan (atletik) yang lebih jauh dan lebih dalam lagi, sehingga pembaca mengetahui dan mampu membaca keadaan-keadaan / permasalah yang terjadi dalam olah raga lompat jauh.

\section{Daftar Pustaka}

Lompat Jauh : Penegertian, Sejarah, Teknik, Gaya, Sarana dan Peraturan

https://dosenpintar.com/lompat-jauh/

LompatJauh,https://www.gurupendidikan.co.id/lompat-jauh/

Lompat Jauh, https://www.yuksinau.id/lompat-jauh/

Makalah Penjas : Olahraga Lompat Jauh, http://sepengatahuanku.blogspot.com/2015/01/makalah-penjas-olahraga

-lompat jauh.html?m=1 